\title{
Laboratory evolution of copper tolerant yeast strains
}

Giusy Manuela Adamo', Stefania Brocca', Simone Passolunghi ${ }^{1}$, Benedetto Salvato ${ }^{2}$ and Marina Lotti ${ }^{*}$

\begin{abstract}
Background: Yeast strains endowed with robustness towards copper and/or enriched in intracellular Cu might find application in biotechnology processes, among others in the production of functional foods. Moreover, they can contribute to the study of human diseases related to impairments of copper metabolism. In this study, we investigated the molecular and physiological factors that confer copper tolerance to strains of baker's yeasts.

Results: We characterized the effects elicited in natural strains of Candida humilis and Saccharomyces cerevisiae by the exposure to copper in the culture broth. We observed that, whereas the growth of Saccharomyces cells was inhibited already at low Cu concentration, $\mathrm{C}$. humilis was naturally robust and tolerated up to $1 \mathrm{~g} \cdot \mathrm{L}^{-1} \mathrm{CuSO}_{4}$ in the medium. This resistant strain accumulated over $7 \mathrm{mg}$ of $\mathrm{Cu}$ per gram of biomass and escaped severe oxidative stress thanks to high constitutive levels of superoxide dismutase and catalase. Both yeasts were then "evolved" to obtain hyper-resistant cells able to proliferate in high copper medium. While in S. cerevisiae the evolution of robustness towards $\mathrm{Cu}$ was paralleled by the increase of antioxidative enzymes, these same activities decreased in evolved hyper-resistant Candida cells. We also characterized in some detail changes in the profile of copper binding proteins, that appeared to be modified by evolution but, again, in a different way in the two yeasts.

Conclusions: Following evolution, both Candida and Saccharomyces cells were able to proliferate up to $2.5 \mathrm{~g} \cdot \mathrm{L}^{-1}$ $\mathrm{CuSO}_{4}$ and to accumulate high amounts of intracellular copper. The comparison of yeasts differing in their robustness, allowed highlighting physiological and molecular determinants of natural and acquired copper tolerance. We observed that different mechanisms contribute to confer metal tolerance: the control of copper uptake, changes in the levels of enzymes involved in oxidative stress response and changes in the copper-binding proteome. However, copper elicits different physiological and molecular reactions in yeasts with different backgrounds.
\end{abstract}

Keywords: yeast, copper, adaptation, evolutionary engineering, oxidative stress response, micronutrients

\section{Background}

Metal ions like copper, manganese, zinc and iron are essential micronutrients for living organisms and play a central role in the cell metabolism being the cofactors of a large number of enzymes and electron transport proteins [1]. The metabolism of copper and the mechanisms that control its intracellular concentration are the targets of intense studies since impairments in $\mathrm{Cu}$ level, transport and localization have been associated with several human diseases $[2,3]$. In fact, while copper deficiency impacts the function of key cell enzymes, $\mathrm{Cu}$

\footnotetext{
* Correspondence: marina.lotti@unimib.it

'Dipartimento di Biotecnologie e Bioscienze, Università degli Studi di MilanoBicocca, Piazza della Scienza 2, 20126 Milano, Italy

Full list of author information is available at the end of the article
}

overload can generate highly reactive oxygen species (ROS) which produce peroxidation of membrane lipids, displacement of other metal cofactors from their natural ligands in signalling proteins [4], oxidation of proteins and cleavage of DNA and RNA molecules [5] resulting in general cellular damage. Moreover, ROS are thought to play a major role in cancer development and in aging [6]. To cope with such strict constraints, all organisms have developed complex regulatory mechanisms to maintain copper homeostasis.

Yeast cells are a good tool both for the investigation and the manipulation of copper metabolism. Studies on the accumulation of metals in edible microorganisms are of relevance for the production of functional foods enriched in micronutrients (for example the ones about

\section{Biomed Central}


the inclusion of iron, cobalt, copper and manganese in yeast cells [7]) and the industrial production of Saccharomyces cerevisiae biomass highly enriched with organic forms of selenium $[7,8]$. Yeast cells resistant to and accumulating intracellular copper have been recently patented for cleaning copper from extracellular solutions [9] and use in pro-biotic, cosmetic, dietary and nutraceuticals products [10].

It has been reported that microorganisms can acquire stress tolerance and novel metabolic abilities when exposed to the appropriate selection pressure. This approach is often reported as "evolutionary engineering", a term introduced by Butler and collaborators in 1996 [11], since it uses evolutionary principles based on the selection of random mutants arising in the microbial population either spontaneously or upon mutagenesis and has been applied for improving complex physiological properties whose genetic and physiological basis is not fully understood [12]. For example, microbial cells were recently evolved to improve their resistance towards multiple stresses [13], cobalt [14], iron- and sulfur-compounds [15], alcohols [16]; and to gain the ability to ferment xylose [17] and lactose [18].

S. cerevisiae is a powerful model organism to investigate copper metabolism and homeostasis in Eukaryotes. As a consequence, a large body of knowledge is available about $\mathrm{Cu}$ uptake, intracellular transport and functional role in yeast cells [19], as well as about non-enzymatic and enzymatic mechanisms of protection from ROS and oxidative stress [20].

In this study, yeast strains endowed with different natural robustness towards copper were compared with strains evolved by stepwise adaptation to tolerate high metal concentrations. We report that different and overlapping physiological and molecular responses are elicited in cells with different backgrounds to allow them to tolerate challenging conditions.

\section{Results}

Tolerance towards copper of one Candida and three Saccharomyces strains was first assessed by a drop test on minimal or rich (YPD) solid medium supplemented with increasing concentrations of copper salt $\left(\mathrm{CuSO}_{4}\right)$ (Figure 1). In good agreement with results from other laboratories showing that the composition of the culture medium and the growth conditions affect copper sensitivity of yeast cells [21,22], we observed that on minimal medium, $0.5 \mathrm{~g} \cdot \mathrm{L}^{-1} \mathrm{CuSO}_{4}$ was sufficient to inhibit the growth of all yeast strains, whereas on YPD plates all of them tolerated up to $1 \mathrm{~g} \cdot \mathrm{L}^{-1} \mathrm{CuSO}_{4}$. However, above this concentration only $C$. humilis cells still proliferated, suggesting low copper tolerance in all strains assayed but $C$. humilis which showed a higher tolerance.

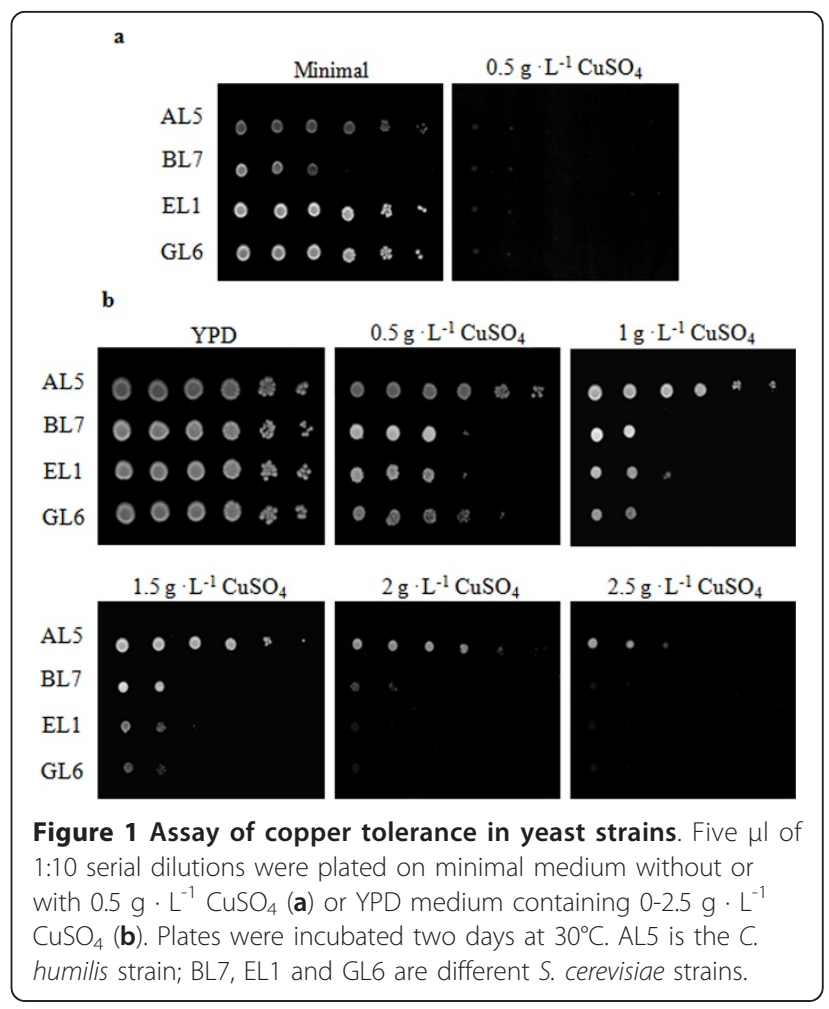

The tolerance of cells to metals is relevant both for understanding the mechanisms of defence towards stress and for the production of microorganisms enriched in a given micronutrient for biotechnological applications. We applied an evolution-based approach to improve robustness towards copper in all strains, independently from their natural background. The experimental protocol relied on the stepwise cultivation of cells in media supplemented with progressively higher concentrations of copper sulphate. At each step the culture was grown for 72 hours before withdrawing aliquots to be inoculated at a higher $\mathrm{CuSO}_{4}$ concentration. The starting condition was YPD $+1 \mathrm{~g} \cdot \mathrm{L}^{-1} \mathrm{CuSO}_{4}$, which is permissive for all strains. The following steps were in YPD + $1.5 \mathrm{~g} \cdot \mathrm{L}^{-1} \mathrm{CuSO}_{4}, \mathrm{YPD}+2 \mathrm{~g} \cdot \mathrm{L}^{-1} \mathrm{CuSO}_{4}$ and YPD + $2.5 \mathrm{~g} \cdot \mathrm{L}^{-1} \mathrm{CuSO}_{4}$. This last one was the highest concentration applied, since above it copper salts led to acidification of the medium resulting in the precipitation of its protein components. Single colonies isolated after the last step of adaptation displayed relatively high rates of growth when directly re-inoculated in YPD $+2.5 \mathrm{~g} \cdot \mathrm{L}^{-1}$ $\mathrm{CuSO}_{4}$. These cells are defined in the following as "evolved".

Figure 2 compares the growth kinetics of non-evolved and evolved cells in YPD $+2.5 \mathrm{~g} \cdot \mathrm{L}^{-1} \mathrm{CuSO}_{4}$ (for simplicity we will refer to this condition as "copper medium"). Among the natural strains (in the following "nonevolved"), only C. humilis AL5 proliferated under this 

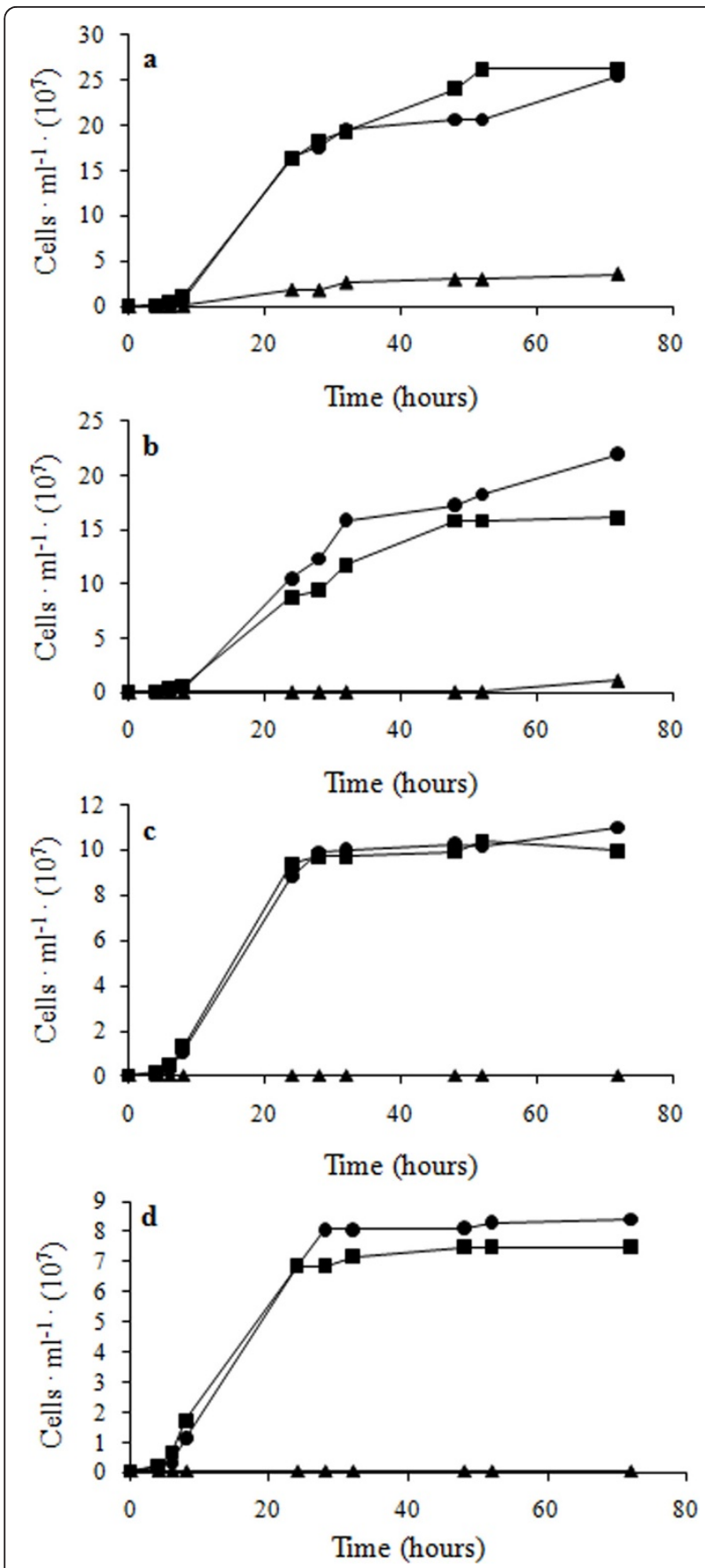

Figure 2 Growth of yeast cells in YPD $+2.5 \mathrm{~g} \cdot \mathrm{L}^{-1} \mathrm{CuSO}_{4}$ Evolved (black cirles), non-evolved (black triangles) and de-adapted (black squares) cells of C. humilis AL5 (a), S. cerevisiae BL7 (b), S. cerevisiae EL1 (c), S. cerevisiae GL6 (d). The values reported are averages of three replicates. Calculated standard deviations are $\leq$ 0.6, making error bars not appreciable.

condition, even though growth started after a prolonged lag phase and a very low final cell density was achieved (Figure 2 a). On the contrary, all evolved strains proliferated in copper medium and reached final biomass densities close to those observed in YPD medium, although with lower growth rate (Additional file 1). Cells subjected to 10 cycles of growth/re-inoculation in YPD without $\mathrm{Cu}$ (referred to as "de-adapted"), retained their ability to proliferate if re-inoculated in copper medium, showing only negligible differences when compared with the corresponding evolved strain (Figure 2 and Additional file 1). This observation suggests that copper tolerance is maintained also in absence of selective pressure. To gain more insight into the behaviour of the copper-sensitive $S$. cerevisiae strains, we compared the kinetics of growth of evolved and non-evolved cells also at $1,1.5$ and $2 \mathrm{~g} \cdot \mathrm{L}^{-1} \mathrm{CuSO}_{4}$ (Additional file 2 ), highlighting a progressive decrease of the proliferation ability of natural cells at increasing copper concentrations. As expected, the same conditions were permissive for evolved Saccharomyces cells.

Analysis of the $\mathrm{Cu}$ content of Candida cell samples from the same cultures shown in Figure 2 revealed relatively high amounts of intracellular copper, i.e. 6.5 and $7.6 \mathrm{mg} \cdot \mathrm{g}^{-1}$ biomass in evolved and non-evolved cells, respectively. The kinetics of bioaccumulation was faster in non-evolved cells where $\mathrm{Cu}$ measured after 24 hours of growth was three times higher than in the evolved ones (Figure 3 a). In copper medium non-evolved Candida grew poorly and contained high copper concentration from the very beginning of the experiment, while $\mathrm{Cu}$ was lower in evolved cells - which proliferated at the same rate as in YPD broth. In both cases, intracellular copper kept increasing up to 48 hours and then reached a plateau. The amount of copper measured in evolved and de-adapted cells grown in copper medium was always comparable, supporting once more the hypothesis that evolutionary engineering produced stable effects.

The increase of intracellular copper in evolved S. cerevisiae was slower and at the end of the experiments we measured 2.1 to $4.2 \mathrm{mg} \mathrm{Cu} \cdot \mathrm{g}^{-1}$ biomass (Figure $3 \mathrm{~b}, \mathrm{c}$, d). The $\mathrm{Cu}$ content of non-evolved and evolved Saccharomyces cells was compared also in a milder condition, (1 $\left.\mathrm{g} \cdot \mathrm{L}^{-1} \mathrm{CuSO}_{4}\right)$. Whereas both kinds of BL7 cells displayed the same kinetics of copper accumulation (Additional file 3), non-evolved EL1 and GL6 showed a faster kinetic of bioaccumulation (Additional file 3) associated to a growth kinetic slower than in their evolved counterpart (Additional file 2). As in Candida samples, also in this case the behaviour of evolved and de-adapted cells was similar.

Results obtained up to this point suggested that all Saccharomyces strains are rather homogeneous in their response to copper, but different from the Candida one. Therefore, subsequent experiments aimed at highlighting possible adaptive changes were focused on a more in-depth comparison between Candida humilis and the only Saccharomyces cells strain BL7. 

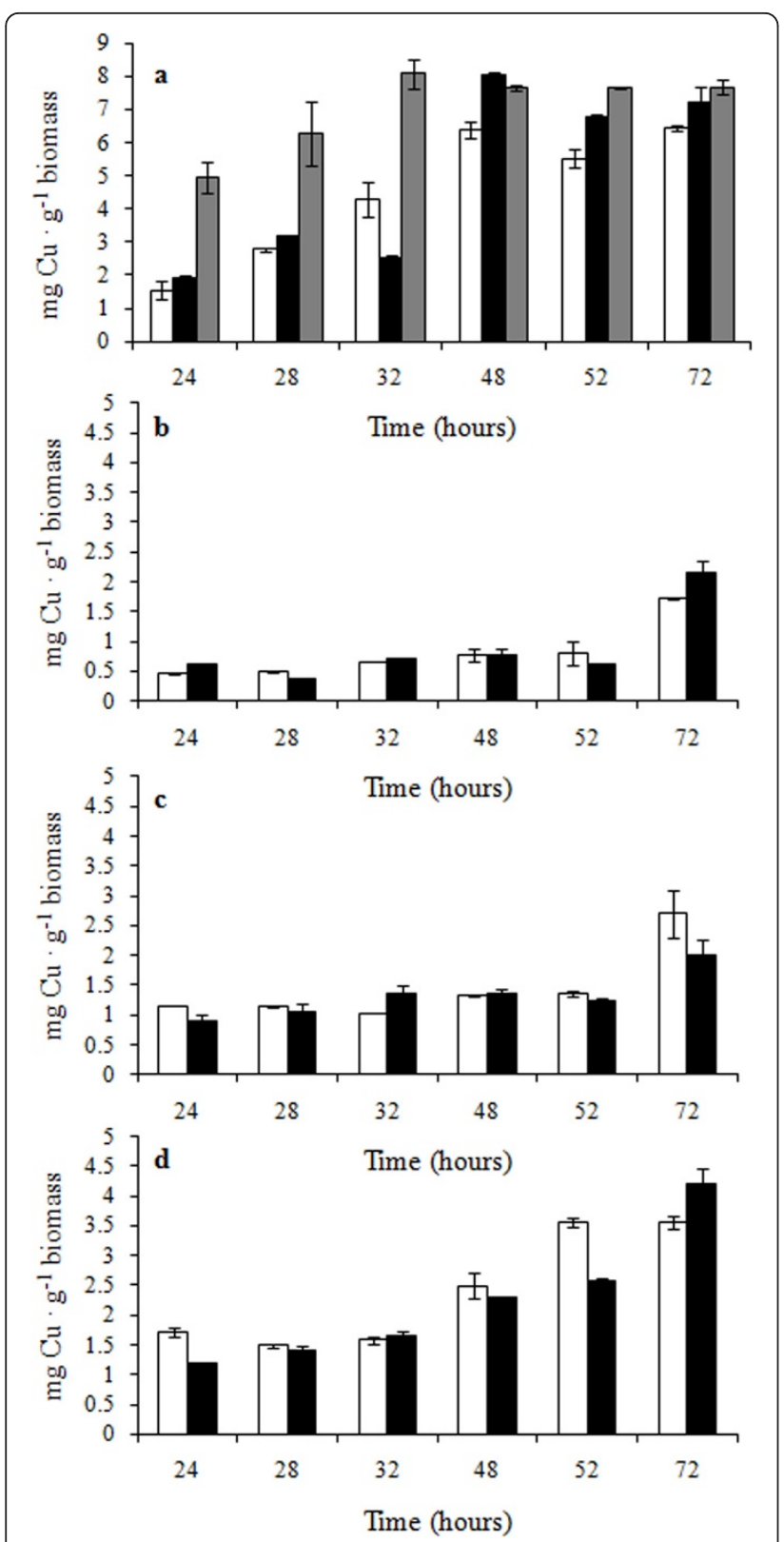

Figure 3 Intracellular copper measured during growth in YPD $+\mathbf{2 . 5} \mathbf{g} \cdot \mathrm{L}^{-1} \mathrm{CuSO}_{4}$. C. humilis AL5 (a); S. cerevisiae BL7 (b); S. cerevisiae EL1 (c) and S. cerevisiae GL6 (d). White bars: evolved cells; black bars: de-adapted cells; grey bars: non-evolved cells. The amount of $\mathrm{Cu}$ is reported as $\mathrm{mg} \cdot \mathrm{g}^{-1}$ biomass. Values are the average of three replicates. Note the change of scale in (a).

Initially, the effect of copper on cell viability was evaluated by citofluorimetry (Figure 4), that allows to get this information at the single cell level [23]. Samples of C. humilis and S. cerevisiae cultures were harvested during exponential growth in copper and stained with propidium iodide, an intercalating agent excluded by viable cells, that can instead permeate the surface of seriously injured/dead cells [24]. In both evolved strains the percentage of propidium-positive cells was lower $(8.5 \%$ for C. humilis and $11 \%$ for S. cerevisiae) than in their non-evolved counterpart (28\% for C. humilis and $60 \%$ for $S$. cerevisiae). The percentage of propidium-positive cells grown in absence of copper (used as a control) was around 2\% (data not shown). Altogether, these results confirm that evolution confers robustness - although not complete insensitivity - to copper. Copper was more detrimental for $S$. cerevisiae than $C$. humilis natural cells, while this difference fainted after adaptive evolution, in good agreement with the kinetics of growth reported in Figure 2.

Since copper is a strong oxidizing agent, we measured the activities of superoxide dismutase, peroxidase, glutathione peroxidase and catalase - all involved in the socalled copper-dependent oxidative stress response - in evolved and non-evolved C. humilis and in evolved $S$. cerevisiae cells harvested from copper medium in the exponential phase of growth. As a control, basal enzymatic activities were determined in YPD-grown cells (Table 1). In S. cerevisiae, exposure to copper resulted in the increase of superoxide dismutase and catalase activities, while peroxidase and glutathione peroxidase activities were only marginally affected. The picture emerging from the analysis of the copper tolerant $C$. humilis strain is different and more exhaustive, since the data set can also include the response of non-evolved cells in copper medium. In all cultivation broths, all enzymatic activities tested in natural Candida cells were 2 to 8 fold higher than in S. cerevisiae. Interestingly enough, we detected high constitutive superoxide dismutase and catalase activities in non-evolved cells, independently from the composition of the culture broth, while peroxidase and glutathione peroxidase activities were induced only by growth in copper medium. Evolution resulted in lower levels of all tested activities in both YPD and copper medium, with the most remarkable effect on superoxide dismutase. Catalase activity that was high in YPD-grown cells (both kinds of cells), strongly decreased in evolved cells grown in copper medium.

We then evaluated the production of reactive oxygen species (ROS) staining cells with dihydroethidium (Figure 5). In presence of superoxide anions in the cytosolic space, this probe is oxidized to the fluorescent product ethidium. Therefore, fluorescence intensity reports on oxidative stress. While in YPD medium the amount of ROS was low in both Candida and Saccharomyces cells, copper exposure clearly triggered oxidative stress, though with milder effects in the evolved cells. Moreover, in agreement with growth and cytofluorimetric data (Figure 2 and 4), the effect on S. cerevisiae was stronger than on Candida with ROS production threefold higher. Evaluation of oxidative stress in S. cerevisiae 


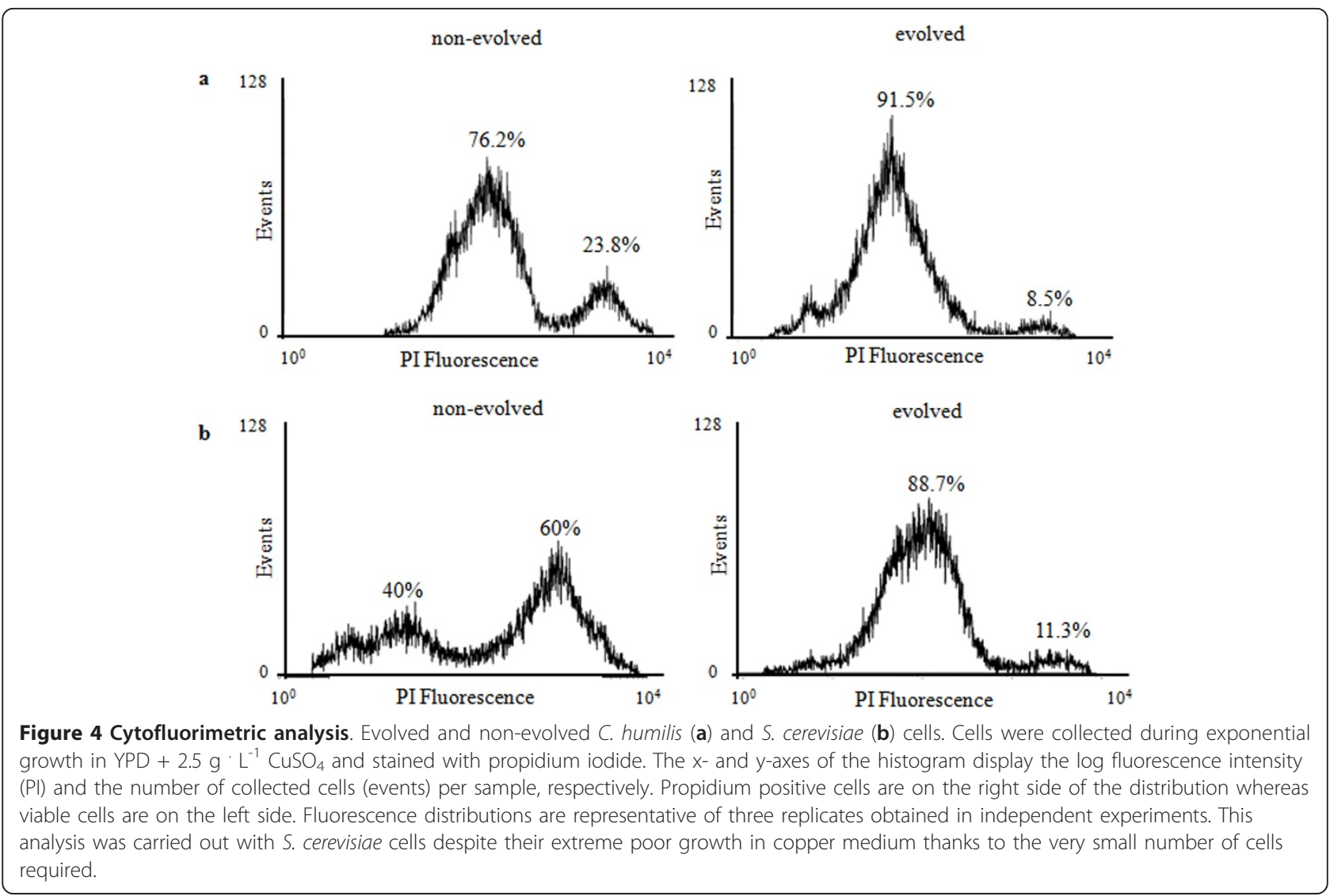

at intermediate metal concentration $\left(1,1.5\right.$ and $2 \mathrm{~g} \cdot \mathrm{L}^{-1}$ $\mathrm{CuSO}_{4}$ ) showed that while ROS production increases with copper concentration in the non-evolved sample, it remains low in the evolved cells (Additional file 4).

Finally we performed a preliminary analysis of the copper-binding proteins extracted from non-evolved and evolved cells grown either in YPD or in copper medium. Samples were enriched by affinity chromatography as described in Materials and Methods and then analysed by SDS-PAGE. Equal volumes of elution fractions obtained from the same amount $(800 \mu \mathrm{g})$ of proteins applied on the column were loaded for the electrophoretic run, therefore assuring that differences detected in the gel reflect changes in composition and content of copper-binding proteins in the starting samples. Figure 6 shows the electrophoretic analysis and Table 2 lists proteins identified by tandem mass spectrometry. The exposure of evolved S. cerevisiae cells to copper elicited the induction of several proteins (Figure 6a, lane 2 and 3) involved in different biochemical and metabolic functions, i.e. the pentose phosphate pathway (band 1), amino acid and sulphur metabolism (bands 2, 3 and 10), glucose metabolism (bands 4 and 7 ), redox reactions (bands 6 and 8), the translation machinery (bands 5 and 9) and isomerization reactions (bands 1 and 9). The same trend was detected at lower $\mathrm{CuSO}_{4}$ concentration

Table 1 Antioxidant enzyme activities in S. cerevisiae and C. humilis cells grown in YPD and in $\mathrm{YPD}^{+} \mathrm{CuSO}_{4} 2.5 \mathrm{~g}^{-\mathrm{L}^{-1}}$ (Cu)

\begin{tabular}{ccccccccc}
\hline & \multicolumn{9}{c}{ S. cerevisiae } & \multicolumn{3}{c}{ C. humilis } \\
\cline { 2 - 9 } & non-evolved & \multicolumn{3}{c}{ evolved } & \multicolumn{3}{c}{ non-evolved } & \multicolumn{3}{c}{ evolved } \\
\cline { 2 - 9 } & YPD & Cu & YPD & Cu & YPD & Cu & YPD & Cu \\
\hline SOD & $20.93 \pm 0$ & n.d & $39.22 \pm 0$ & $64.14 \pm 0.92$ & $132.97 \pm 17.09$ & $117.2 \pm 21.26$ & $32.34 \pm 1.08$ & $41.1 \pm 8.42$ \\
Catalase & $3.2 \pm 0.45$ & n.d & $3.23 \pm 0.45$ & $11.82 \pm 1.26$ & $81.5 \pm 5.17$ & $73.76 \pm 6.74$ & $74.14 \pm 11.46$ & $27.7 \pm 4.4$ \\
Peroxidase & $0.001 \pm 0$ & n.d & $0.0032 \pm 0$ & $0.004 \pm 0$ & $0.011 \pm 0.001$ & $0.019 \pm 0.003$ & $0.014 \pm 0$ & $0.008 \pm 0$ \\
GPO & $0.041 \pm 0.001$ & n.d & $0.012 \pm 0.001$ & $0.013 \pm 0.009$ & $0.19 \pm 0.024$ & $0.534 \pm 0.039$ & $0.235 \pm 0.039$ & $0.172 \pm 0.07$ \\
\hline
\end{tabular}

Activities measured were superoxide dismutase (SOD), catalase, peroxidase and glutathione peroxidase (GPO). Values, reported as $U \cdot \mathrm{mg}^{-1}$ of proteins, are average of three independent measurements. n.d.: not determined due to lack of viable cells. 

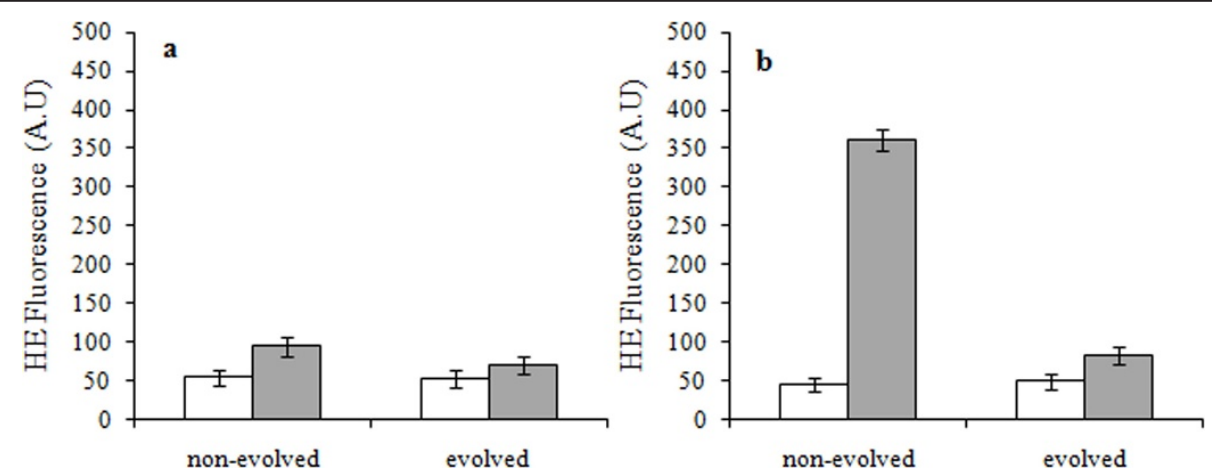

Figure 5 Fluorimetric analysis of superoxide anion $\left(\mathrm{OH}^{-*}\right)$ production. Evolved and non-evolved C. humilis (a) and S. cerevisiae (b) cells exponentially growing in YPD (white bars) and in YPD $+2.5 \mathrm{~g}^{\cdot} \mathrm{L}^{-1} \mathrm{CuSO}_{4}$ (grey bars). $\mathrm{OH}^{-*}$ formation is expressed as fluorescence intensity of ethidium in arbitrary units. Data presented are the mean of at least three independent analyses.

(data not shown). The picture relevant to Candida is completely different (Figure 6 b). Non-evolved Candida cells react to copper repressing a number of $\mathrm{Cu}$-binding proteins that would be otherwise expressed during growth in YPD (Figure 6b, lane 1 and lane 3). Among the down-regulated proteins we could identify ribosomal proteins and components of the protein translation apparatus (band 11, 13 and 16). The profile of $\mathrm{Cu}$-binding proteins extracted from evolved Candida cells (Figure 6, lane 2 and 4) showed a massive enrichment of a protein of $\sim 35 \mathrm{kDa}$ (band 14), identified as glyceraldehyde-3-posphate dehydrogenase 3 (GAPDH). We further observed the increase of a protein of $\sim 22 \mathrm{kDa}$ (band 15 ) identified as peroxiredoxin and of a protein inducible by oxidative stress (band 12).

\section{Discussion}

In this work, we obtained copper-enriched and coppertolerant yeasts through a number of generations smaller than reported in similar recent works $[13,14,25]$. This

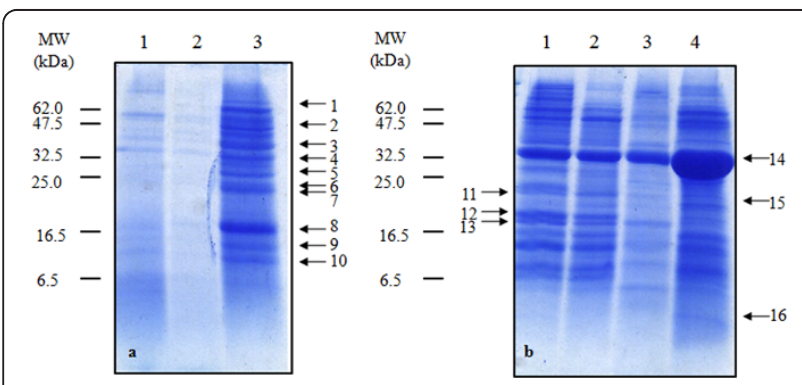

Figure 6 SDS-PAGE of copper-binding proteins. (a) S. cerevisiae Lane 1: proteins from non-evolved cells grown in YPD; lane 2: proteins from evolved cells grown in YPD; lane 3: proteins from evolved cells grown in YPD $+\mathrm{CuSO}_{4} 2.5 \mathrm{~g} \cdot \mathrm{L}^{-1}$. (b) C. humilis. Lane 1: proteins from non-evolved cells grown in YPD; lane 2: proteins from evolved cells grown in YPD; lane 3: proteins from non-evolved cells grown in YPD $+\mathrm{CuSO}_{4} 2.5 \mathrm{~g} \cdot \mathrm{L}^{-1}$; lane 4: proteins from evolved cells grown in YPD $+\mathrm{CuSO}_{4} 2.5 \mathrm{~g} \cdot \mathrm{L}^{-1}$. might be explained on the basis of a different experimental set-up in which relatively few rounds of selection were applied, but with longer cultivation times $(72 \mathrm{~h})$ and wider intervals of metal concentration (increases of 0.5 g. $\mathrm{L}^{-1}$ at each round). The effectiveness of the

Table 2 Identification of copper-binding proteins

\begin{tabular}{|c|c|c|c|}
\hline $\begin{array}{c}\text { Band } \\
\mathrm{n}^{\circ}\end{array}$ & Protein $^{a}$ & $\begin{array}{c}\text { MW } \\
(\mathrm{kDa})\end{array}$ & $\begin{array}{c}\mathrm{n}^{\circ} \\
\text { peptides }^{\mathrm{b}}\end{array}$ \\
\hline \multirow[t]{2}{*}{1} & Transketolase 1 & 73.87 & 4 \\
\hline & Protein disulfide-isomerase & 58.53 & 1 \\
\hline \multirow[t]{2}{*}{2} & NADP glutamate dehydrogenase 1 & 49.88 & 14 \\
\hline & NADP glutamate dehydrogenase 2 & 49.93 & 6 \\
\hline \multirow[t]{2}{*}{3} & $\begin{array}{l}\text { Aspartate-semialdehyde } \\
\text { dehydrogenase }\end{array}$ & 40.03 & 3 \\
\hline & Cystathionine- $\gamma$-lyase & 42.51 & 4 \\
\hline 4 & $\begin{array}{l}\text { Glyceraldehyde-3-phosphate } \\
\text { dehydrogenase }\end{array}$ & 35.83 & 4 \\
\hline 5 & Elongation factor $1-\beta$ & 22.67 & 3 \\
\hline 6 & $\begin{array}{c}\text { Uncharacterized oxidoreductase } \\
\text { YMR226C }\end{array}$ & 29.19 & 3 \\
\hline 7 & Triose phosphate isomerase & 26.89 & 3 \\
\hline 8 & Cu, Zn-superoxide dismutase & 15.95 & 3 \\
\hline \multirow[t]{2}{*}{9} & Peptidyl-prolyl cis-trans isomerase & 17.49 & 2 \\
\hline & 40 S ribosomal protein S26-A & 13.72 & 1 \\
\hline 10 & $\begin{array}{c}\text { Hypothetical protein YIL051C (or } \\
\text { MMF1) }\end{array}$ & 15.95 & 3 \\
\hline 11 & $60 S$ ribosomal protein L19 & 21.69 & 1 \\
\hline 12 & Hypothetical protein YDR032C & 20.96 & 1 \\
\hline 13 & $\begin{array}{l}\text { Eucaryotic translation initiation factor } \\
\qquad 5 \mathrm{~A}-2\end{array}$ & 17.21 & 1 \\
\hline \multirow[t]{2}{*}{14} & $\begin{array}{c}\text { Glyceraldehyde-3-phosphate } \\
\text { dehydrogenase } 2\end{array}$ & 35.93 & 3 \\
\hline & $\begin{array}{l}\text { Glyceraldehyde-3-phosphate } \\
\text { dehydrogenase } 3\end{array}$ & 35.83 & 4 \\
\hline 15 & Peroxiredoxin TSA1 & 21.69 & 1 \\
\hline 16 & Ubiquitin-40S ribosomal protein S31 & 17.43 & 2 \\
\hline
\end{tabular}

${ }^{a}$ ESI-MS indicates that bands 1, 2, 3, 9 and 14 contain more than one protein ${ }^{\mathrm{b}}$ number of peptides analyzed by ESI-MS 
method of evolution is substantiated by the preservation of metal tolerance in absence of selective pressure (deadapted cells), meaning that stable molecular changes occurred. This view is corroborated by the amplification of the CUP1 gene, which encodes for a metallothionein, detected in evolved $S$. cerevisiae cells (Adamo et al., in preparation). However, it is possible that other adaptive (transient) modifications contribute to the increased resistance.

In the frame of this complex picture, the comparison of yeasts differing in their robustness towards copper allowed us to investigate physiological differences involved in natural and acquired copper tolerance and to obtain some preliminary information about the molecular determinants of this trait. Taken together, our results hint at the concurrence of different mechanisms that we briefly summarize and discuss in the following.

i) Copper uptake. C. humilis cells can grow in copper medium due to their natural tolerance that can be further improved via evolutionary engineering. This feature allowed to compare the bioaccumulation of intracellular $\mathrm{Cu}$ in non-evolved and evolved cells at the highest copper concentration used $\left(2.5 \mathrm{~g} \cdot \mathrm{L}^{-1} \mathrm{CuSO}_{4}\right)$, showing that copper is lower in these latter. On this basis we hypothesize that one of the mechanisms of robustness might rely on hindering metal uptake. Consistently, the toxicity of $\mathrm{Cu}$ incorporated in the nonevolved strain (mainly in the first hours of growth) might account for the growth impairment and the increase in the rate of propidium positive cells we observed. In this light, the variability in copper sensitivity between Candida and Saccharomyces cells might depend (at least partly) on a different ability to limit copper uptake and its overload. Such a mechanism has been reported to protect $S$. cerevisiae cells from copper [26] cadmium [27] and cobalt [14] and points to a central role of the plasma membrane [28-30] and of the cell wall [31] in the onset of tolerance to heavy metals.

ii) Antioxidative enzymes and ROS production. Our results indicate that the biochemical bases of copper resistance can be deeply different among yeast species. In $S$. cerevisiae, evolution of copper tolerance is associated with the increase of antioxidative activities, as already documented by others [32], and with a reduced production of ROS. On the contrary, non-evolved cells suffer severe oxidative stress, as showed by the complete inhibition of their growth and the huge percentage of propidium positive cells. Basal activities of most detoxifying enzymes are higher in $C$. humilis than in $S$. cerevisiae cells, fact that could partly explain the natural copper tolerance of Candida cells and the reduced ROS production. The response of evolved Candida cells to copper is intriguing since our results show a reduction in the production of ROS, a generalised decrease of the antioxidative activities, and non-responsiveness to copper (compare values reported for evolved cells in YPD and copper medium). Indeed, in evolved cells superoxide dismutase is always lower than in the original strain, independently from the presence of copper. We would assume that the different activity profiles and their reshaping upon evolution might reflect different and peculiar defence mechanisms responsible for both natural and acquired copper tolerance in Saccharomyces and Candida strains.

iii) $\mathrm{Cu}$-binding proteins. The hypothesis above is further corroborated by the observation that the amounts of soluble $\mathrm{Cu}$-binding proteins extracted from non-evolved and evolved cells are different too. Over-expression of $\mathrm{Cu}$ binding proteins is consistent with their role in the primary response to copper exposure and results in copper tolerance [33]. We are aware that the enrichment procedure used might lead to overestimation of some proteins that carry modifications such as thiolation [34,35] or sequence motives that increase their affinity for the chromatographic resin or to underestimation of low-affinity proteins. Nevertheless, the differences detected between the two yeasts are marked and relevant proteins identified are in agreement with literature data reported by others. Among $\mathrm{Cu}$-binding proteins, enzymes involved in sulphur metabolism (i.e. cystathionine- $\gamma$-lyase and aspartate-semialdehyde dehydrogenase) were over-expressed by evolved S. cerevisiae cells during growth in copper medium, suggesting that copper might redirect the metabolic flux towards the production of GSH to balance the redox equilibrium. The over-expression of glycolytic enzymes such as triose phosphate isomerase and GAPDH3 might be a consequence of the reconfiguration of the glycolytic flux, a mechanism reported to regulate the response to oxidative stress in human [36], plant [37] and yeast [38] cells. Furthermore, the increase of GAPDH3 is consistent with the role of this protein as a sensor of oxidative stress in DNA repair [39] and apoptosis [40,41]. GAPDH3 increase is also the most remarkable effect triggered by copper in evolved $C$. humilis. Besides, these cells are enriched in the peroxiredoxin Tsa1 $[42,43]$, known to act as antioxidant against ROS [44] and to protect actively translating ribosomes from stress conditions [45]. On this basis we propose that in evolved Candida cells the inhibition of protein synthesis associated with oxidative stress [46] occurs in an attenuated form in comparison to nonevolved cells, that show a strong decrease of $\mathrm{Cu}$-binding proteins, without any remarkable down regulation of the ribosomal proteins and other components of the protein translation apparatus.

\section{Conclusion}

The comparison between yeast cells naturally resistant or experimentally evolved to tolerate high copper 
concentration reported in this work supports the view that copper tolerance is due to multiple responses relying on different physiological and macromolecular changes. Yeasts endowed with copper tolerance and able to accumulate metal ions can find application in the biotechnology field for example for bioremediation or as dietary supplement, being these "GRAS organisms" valuable sources of microelements in organic form. Moreover, the comprehension of physiological and molecular responses of microorganisms to metal stress and of the mechanisms triggered during evolution of tolerance could help in the identification of biomarkers for ecotoxicological studies.

\section{Methods}

\section{Yeast strains and growth conditions}

Yeasts used in this study were isolated from sourdough. Strains were identified by Random Amplification of Polymorphic DNA-PCR (RAPD-PCR) and designated as Candida humilis AL5, and Saccharomyces cerevisiae BL7, EL1 and GL6 (Veneto Agricoltura - Istituto per la Qualità e le Tecnologie Agroalimentari - VI). Growth was on YPD medium [2\% (w/v) glucose, $1 \%(\mathrm{w} / \mathrm{v})$ yeast extract, $2 \%(\mathrm{w} / \mathrm{v})$ tryptone] or on minimal medium $[2 \%$ $(\mathrm{w} / \mathrm{v})$ glucose, $0.67 \%(\mathrm{v} / \mathrm{v})$ yeast nitrogen base]. Solid media contained $2 \%(\mathrm{w} / \mathrm{v})$ agar.

Copper tolerance was tested on cells grown shaking over night in $3 \mathrm{~mL}$ of liquid YPD at $30^{\circ} \mathrm{C}$ and subjected to serial dilutions in physiological solution $[0.9 \%(\mathrm{w} / \mathrm{v})$ $\mathrm{NaCl}$. $5 \mu \mathrm{L}$ aliquots were spotted on either YPD or minimal medium plates containing $\mathrm{CuSO}_{4}$ and incubated at $30^{\circ} \mathrm{C}$ for 2 days.

Adaptative evolution was performed stepwise starting from cells taken from a fresh culture on agarized YPD and grown overnight at $30^{\circ} \mathrm{C}$ in $3 \mathrm{~mL}$ of liquid $\mathrm{YPD}+1$ $\mathrm{g} \cdot \mathrm{L}^{-1} \mathrm{CuSO}_{4}$. In the subsequent steps, $5 \times 10^{5}$ cells from stationary cultures were inoculated and cultivated for 72 hours in fresh medium containing each time increasing concentrations of copper $\left(1.5-2-2.5 \mathrm{~g} \cdot \mathrm{L}^{-}\right.$ $\left.{ }^{1}\right)$. Single colonies were isolated from the culture on YPD $+2.5 \mathrm{~g} \cdot \mathrm{L}^{-1} \mathrm{CuSO}_{4}$ by plating on solid YPD and re-inoculated in liquid YPD $+2.5 \mathrm{~g} \cdot \mathrm{L}^{-1} \mathrm{CuSO}_{4}$. To assess the endurance of metal tolerance, evolved cells were subjected to 10 cycles of inoculation-growth in fresh YPD medium without copper (de-adaptation) prior to be cultivated again in YPD $+2.5 \mathrm{~g} \cdot \mathrm{L}^{-1} \mathrm{CuSO}_{4}$.

Growth of non-evolved and evolved S. cerevisiae cells (BL7, EL1 and GL6) was assayed in liquid YPD medium supplemented with intermediate copper concentrations $\left(1,1.5,2 \mathrm{~g}, \cdot \mathrm{L}^{-1} \mathrm{CuSO}_{4}\right)$.

Growth was determined as the increase of cells number using a cells counter (Particle Count \& Size Analyzer, Beckman Coulter).

\section{Copper determination}

Cells were harvested from $2 \mathrm{~mL}$ culture by centrifugation at $10,000 \mathrm{~g}$ for $10 \mathrm{~min}$, washed twice with deionized water and at least four times with $10 \mathrm{mM}$ citric acid in $0.5 \%(\mathrm{w} / \mathrm{v}) \mathrm{NaCl}$ to remove copper ions adsorbed on the cell surface. The biomass was dried by Max-Dry Iyo (Heto) for $30 \mathrm{~min}$, re-suspended in $300 \mu \mathrm{L}$ of $20 \%$ $(\mathrm{w} / \mathrm{v})$ trichloroacetic acid (TCA), transferred to a $2 \mathrm{~mL}$ screw cap tube containing $100 \mu \mathrm{L}$ of glass microbeads and subjected to mechanical lysis by three cycles of 20 sec at maximum speed with a Fast Prep ${ }^{\circledR}$ - FP120 (Bio101-Savant). The crude extract was clarified by centrifugation at $10,000 \mathrm{~g}$ for $10 \mathrm{~min}$ and the supernatant transferred to a new tube. Copper was quantified according to Brenner and Harris [47] adapted as follow. The clarified crude extract was diluted in $500 \mu \mathrm{L}$ of deionized water and added to $100 \mu \mathrm{L}$ of $1 \%(\mathrm{w} / \mathrm{v})$ ascorbic acid and $400 \mu \mathrm{L}$ of "BCA reagent" [0.006\% (w/v) 2,2'biquinoline-4,4'-dicarboxylic acid disodium salt hydrate (Fluka), 3.6\% (w/v) NaOH, 15.6\% (w/v) Hepes]. After 2 min incubation at room temperature, absorbance was recorded at $354 \mathrm{~nm}$ with a spectrophotometer Ultraspec 1000 (Pharmacia Biotec). The amount of copper is referred as $\mathrm{mg} \mathrm{Cu} \cdot \mathrm{g}^{-1}$ dry biomass.

\section{Flow cytometry analysis}

Samples containing $10^{7}$ cells were withdrawn during the exponential growth phase. Cells were harvested by centrifugation, washed twice with deionized water and four times with $10 \mathrm{mM}$ citric acid in $0.5 \%(\mathrm{w} / \mathrm{v}) \mathrm{NaCl}$. Cells were washed with $1 \mathrm{~mL}$ of PBS $\left(3.3 \mathrm{mM} \mathrm{NaH}_{2} \mathrm{PO}_{4}, 6.7\right.$ $\mathrm{mM} \mathrm{Na}_{2} \mathrm{HPO}_{4}, 127 \mathrm{mM} \mathrm{NaCl}, 0.2 \mathrm{mM}$ EDTA) and stained with $1 \mathrm{~mL}$ of the fluorescent probe propidium iodide $\left(5 \mathrm{ng} \cdot \mathrm{mL}^{-1}\right)$. Stained cells were sonicated for 15 sec and then analyzed using a Cell Lab Quanta ${ }^{\text {TMSC }}$ flow cytometer (Beckman Coulter) equipped with a diode laser (excitation wavelength $488 \mathrm{~nm}$, laser power $22 \mathrm{~mW})$. The fluorescence emission was measured through a $670 \mathrm{~nm}$ long pass filter (FL3 parameter) in logarithmic mode for propidium iodide (PI) signal. Not stained and ethanol-treated samples were used as controls. The sample flow rate during analysis did not

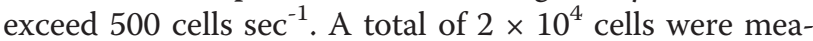
sured for each sample. Data analysis was performed with WinMDI 2.8 software, build\#13 01-19-2000 (Purdue University, Cytometry Laboratories http://facs.scripps. edu/software.html).

\section{Preparation of cell-free extracts}

Cells from exponential cultures were harvested by centrifugation at 4,900 $\mathrm{g}$ for $10 \mathrm{~min}$ and washed twice with cold deionised water and four times with cold $10 \mathrm{mM}$ citric acid in $0.5 \%(\mathrm{w} / \mathrm{v}) \mathrm{NaCl}$. The cell pellet was finally 
re-suspended in $0.5 \mathrm{M}$ Tris- $\mathrm{Cl} \mathrm{pH} 8.5,0.25 \mathrm{M}$ EDTA $\mathrm{pH} 8.4$ added with protease inhibitor cocktail (Sigma) and mechanically disrupted using glass microbeads. Cell debris was removed by centrifugation at $700 \mathrm{~g}$ for 10 min and the clarified crude extract was used for enzymatic analyses. The protein concentration in cell-free extracts was estimated according to Bradford [48] using bovine serum albumin as the reference.

\section{Enzyme assays}

Enzyme activities were measured on cell-free extracts by spectrophotometric assays. Activities were expressed as Units $\cdot \mathrm{mg}^{-1}$ proteins. Catalase activity was determined according to Bergmeyer [49] monitoring hydrogen peroxide decrease at $240 \mathrm{~nm}$. Superoxide dismutase activity was measured as the inhibition of the rate of reduction of cytochrome c by the superoxide radical, observed at $550 \mathrm{~nm}$ [50]. Peroxidase activity was measured following the oxidation of pyrogallol at $420 \mathrm{~nm}$ [51]. The activity of glutathione peroxidase was determined monitoring NADPH oxidation at $340 \mathrm{~nm}$ [52].

\section{Purification of copper-binding proteins}

Supernatants obtained by ultracentrifugation $(18,000 \mathrm{~g}$, $45 \mathrm{~min}$ ) of cell extracts were heated at $65^{\circ} \mathrm{C}$ for $10 \mathrm{~min}$ to enrich thermostable proteins, since thermostability is common to several copper-binding proteins [53]. Samples were then centrifugated at $10,000 \mathrm{~g}$ for $10 \mathrm{~min}$ and supernatants purified by affinity chromatography on a Sepharose Chelating resin (Sigma) loaded with $0.2 \mathrm{M}$ $\mathrm{CuSO}_{4}$ (copper resin). Samples (ca. $800 \mu \mathrm{g}$ protein) were incubated for $20 \mathrm{~min}$ with $0.5 \mathrm{~mL}$ of copper resin previously equilibrated with $1 \mathrm{~mL}$ of binding buffer (0.02 $\mathrm{M} \mathrm{Na}_{2} \mathrm{HPO}_{4}, 0.5 \mathrm{M} \mathrm{NaCl}, \mathrm{pH}$ 7.2). Unbound proteins were removed by gravity flow and the column washed three times with $0.5 \mathrm{~mL}$ of binding buffer. Bound proteins were eluted first with $0.02 \mathrm{M} \mathrm{Na}_{2} \mathrm{HPO}_{4}$, $0.5 \mathrm{M} \mathrm{NaCl}, \mathrm{pH} 3.5$ and then with $0.02 \mathrm{M} \mathrm{Na}_{2} \mathrm{HPO}_{4}$, $0.5 \mathrm{M} \mathrm{NaCl}, 0.05 \mathrm{M}$ EDTA, pH 7.2. Proteins from 200 $\mu \mathrm{L}$ of each elution fraction were precipitated with $60 \mu \mathrm{l}$ of $20 \%(\mathrm{w} / \mathrm{v})$ TCA, resuspended in $50 \mu \mathrm{L}$ of SDS-Sample buffer $(0.25 \mathrm{M}$ Tris-Cl pH 6.8, 50\% (v/v) glycerol, $10 \%$ $(\mathrm{w} / \mathrm{v})$ sodium dodecyl sulphate, $5 \%(\mathrm{v} / \mathrm{v}) \beta$-mercaptoethanol, $0.25 \%(\mathrm{w} / \mathrm{v})$ bromophenol blue), heated at $99^{\circ}$ $\mathrm{C}$ for $5 \mathrm{~min}$ and applied to $18 \%(\mathrm{w} / \mathrm{v})$ polyacrylamide gels. Electrophoresis in denaturing conditions (SDSPAGE) was carried out according to Laemmli [54]. Gels were stained by GelCode Blue (Pierce).

\section{Mass spectrometry}

Bands were excised from the polyacrylamide gels, cut into small pieces and de-stained by repeated washing cycles alternating $50 \mathrm{mM}$ ammonium hydrogen carbonate and pure acetonitrile. After complete destaining, gel particles were dehydrated by acetonitrile, covered with trypsin solution $(12.5 \mathrm{ng} / \mathrm{mL}$ in $50 \mathrm{mM}$ ammonium hydrogen carbonate, $\mathrm{pH} 8.0$ ) and incubated $1 \mathrm{~h}$ on ice. Excess liquid was removed and the gel pieces covered with a solution of $50 \mathrm{mM}$ ammonium hydrogen carbonate $(\mathrm{pH} 8.0)$ and incubated overnight at $37^{\circ} \mathrm{C}$. Tryptic peptides were extracted by alternating incubation in pure acetonitrile and 1\% formic acid. Samples were lyophilised, resuspended in 1\% formic acid, and desalted by ZipTip (Millipore) before ESI-MS analysis.

ESI-MS experiments were performed with a hybrid Quadrupole-Time-of-Flight (q-TOF) mass spectrometer (QSTAR ELITE, Applied Biosystems) equipped with a nano-electrospray ionisation sample source. Metalcoated borosilicate capillaries (Proxeon, Denmark) with medium-length emitter tip of $1-\mu \mathrm{m}$ internal diameter were used for off-line analysis. The instrument was calibrated with standard solution Renin $(\mathrm{MH} 2+879.97 \mathrm{Da}$ and its fragment $\mathrm{MH}+110.07 \mathrm{Da}$, Applied Biosystems). Peptide identification was performed using the $M A S$ COT software with the following parameters: 2 missed cleavages, peptide tolerance $0.6 \mathrm{Da}, \mathrm{MS} / \mathrm{MS}$ tolerance $0.6 \mathrm{Da}$, peptide charges $2+$ and $3+$. Only monoisotopic masses were considered as precursor ions.

Spectra of tryptic peptides were acquired in the 400$1,500 \mathrm{~m} / \mathrm{z}$ range, with $1.0 \mathrm{sec}$ accumulation time, ionspray voltage $1,3000 \mathrm{~V}$, declustering potential $60 \mathrm{~V}$, with active Information Dependent Acquisition (IDA), using rolling collision energy to fragment peptides for MS/MS analysis.

\section{Determination of Reactive Oxygen Species}

Samples containing $5 \times 10^{6}$ cells were withdrawn from exponential cultures. Cells were harvested by centrifugation, washed twice with de-ionized water, four times with $10 \mathrm{mM}$ citric acid in $0.5 \%(\mathrm{w} / \mathrm{v}) \mathrm{NaCl}$, once with 1 $\mathrm{mL}$ of PBS and finally incubated with $0.5 \mathrm{~mL}$ of $5 \mu \mathrm{M}$ (v/v) dihydroethidium (Sigma, stock solution $30 \mathrm{mM}$ in DMSO) for $30 \mathrm{~min}$ in the dark. Stained cells were washed three times with PBS and sonicated for 15 sec. The fluorescence signal was detected using a Cary Eclipse spectrofluorimeter (Varian, CA, USA) at excitation wavelength of $518 \mathrm{~nm}$ and emission wavelength of $605 \mathrm{~nm}$. Fluorescence values were normalized against those of not stained cells.

\section{Additional material}

\footnotetext{
Additional file 1: Table. Specific growth rate $\left(h^{-1}\right)$ and final cell density (cells $\cdot \mathrm{mL}^{-1}$ ) $\cdot 10^{7}$ of non-evolved, evolved and de-adapted cells from $C$ humilis AL5, and S. cerevisiae BL7, EL1 and GL6 strains grown on YPD and/or YPD $+2.5 \mathrm{~g} \cdot \mathrm{L}^{-1} \mathrm{CuSO}_{4}(\mathrm{Cu})$. n.d.: not determined.

Additional file 2: Growth of yeast cells in YPD supplemented with 1, 1.5 and $2 \mathbf{~ g} \cdot \mathbf{L}^{-1} \mathbf{C u S O}_{4}$. Evolved (black circles), non-evolved (black triangles) cells of S. cerevisiae BL7 (a), S. cerevisiae EL1 (b), S. cerevisiae GL6
} 
(c). The values reported are averages of three replicates. For values of standard deviations $\leq 0.6$ error bars are not appreciable.

Additional file 3: Intracellular copper measured during growth in YPD $+1 \mathbf{~ g} \cdot \mathrm{L}^{-1} \mathrm{CuSO}_{4}$. S. cerevisiae BL7 (a); S. cerevisiae EL1 (b) and S. cerevisiae GL6 (c). White bars: evolved cells; grey bars: non-evolved cells. The amount of $\mathrm{Cu}$ is reported as $\mathrm{mg} \cdot \mathrm{g}^{-1}$ biomass. Values are the mean of three replicates.

Additional file 4: Fluorimetric analysis of superoxide anion $\left(\mathrm{OH}^{-*}\right)$ production in S. cerevisiae $\mathrm{BL7}$ growing at different $\mathrm{CuSO}_{4}$ concentration. Detection of $\mathrm{OH}^{-}$was carried out after growth in YPD and in YPD supplemented with $1,1.5$ and $2 \mathrm{~g} \cdot \mathrm{L}^{-1} \mathrm{CuSO}_{4}$. White bars: evolved cells; grey bars: non-evolved cells. $\mathrm{OH}^{-*}$ formation is expressed as fluorescence intensity of ethidium in arbitrary units. Data presented are the mean of at least three independent analyses.

\section{Acknowledgements}

Authors wish to thank Angiolella Lombardi of Veneto Agricoltura - Istituto per la Qualità e le Tecnologie Agroalimentari (VI) - for providing the yeast strains and Maria Šamalíková for technical support in MS analysis. G.M.A. is the recipient of a PhD fellowship of the University of Milano-Bicocca.

\section{Author details}

'Dipartimento di Biotecnologie e Bioscienze, Università degli Studi di MilanoBicocca, Piazza della Scienza 2, 20126 Milano, Italy. ${ }^{2}$ Dipartimento di Biologia, Università di Padova, Via Ugo Bassi, 58/B, 35121 Padova, Italy

\section{Authors' contributions}

GMA performed most of the physiological and biochemical characterization of yeasts. SB participated in the design of experiments and in the analysis of results. SP designed and carried out the experiments of cytofluorimetry. BS drew attention on the importance of Cu tolerance in yeast and suggested the experimental strategy of adaptation. ML conceived this study, contributed to the interpretation of results and drafted the paper. All authors read and approved the final manuscript.

\section{Competing interests}

The authors declare that they have no competing interests.

Received: 27 August 2011 Accepted: 3 January 2012

Published: 3 January 2012

\section{References}

1. Gadd GM: Metals and microorganisms: a problem of definition. FEMS Microbiol Lett 1992, 79:197-203.

2. Waggoner DJ, Bartnikas TB, Gitlin JD: The role of copper in neurodegenerative disease. Neurobiol Dis 1999, 6:221-230.

3. De Freitas J, Wintz H, Kim JH, Poynton H, Fox T, Vulpe C: Yeast, a model organism for iron and copper metabolism studies. Biometals 2003, 16:185-197.

4. Pena MMO, Koch KA, Thiele DJ: Dynamic regulation of copper uptake and detoxification genes in Saccharomyces cerevisiae. Mol Cell Biol 1998, 18:2514-2523

5. Halliwell B, Gutteridge JM: Oxygen toxicity, oxygen radicals, transition metals and disease. Biochem J 1984, 219:1-14.

6. Halliwell B, Gutteridge JM: Role of free radicals and catalytic metal ions in human disease: an overview. Methods Enzymol 1990, 186:1-85.

7. Bass-Shakhdan HF: On opportunity of yeast to increase food value. Problems of healthy and sick human nutrition AN Larvian SSR Edition 1960, 107-115.

8. Zolotov PA, Tutelyan VA, Knyazhev VA: A metod of baker's yeast production. Russian Federation Patent 21033521998.

9. Abe F, Horikoshi K: Copper tolerant yeast and pectinases produced by the yeast. US Patent PCT/JP2001/002255 2001.

10. Manzoni M, Rollini SM, Benedetti A: Copper-enriched biomass, method for the preparation thereof and pro-biotic cosmetic, dietary and neutraceutic products comprising the same. U S Patent PCT/1B2009/053072 2009 .
11. Butler PR, Brown M, Oliver SG: Improvement of antibiotic titers from Streptomyces bacteria by interactive continuous selection. Biotechnol Bioeng 1996, 49:185-196.

12. Sauer U: Evolutionary engineering of industrially important microbial phenotypes. Adv Biochem Eng Biotechnol 2001, 73:129-169.

13. Cakar ZP, Seker UO, Tamerler C, Sonderegger M, Sauer U: Evolutionary engineering of multiple-stress resistant Saccharomyces cerevisiae. FEMS Yeast Res 2005, 5:569-578.

14. Cakar ZP, Alkim C, Turanli B, Tokman N, Akman S, Sarikaya M, Tamerler C, Benbadis L, Francois JM: Isolation of cobalt hyper-resistant mutants of Saccharomyces cerevisiae by in vivo evolutionary engineering approach. J Biotechnol 2009, 143:130-138.

15. Rawlings DE: Characteristics and adaptability of iron- and sulfur-oxidizing microorganisms used for the recovery of metals form metals and their concentrates. Microbial cell factories 2005, 4

16. Minty JJ, Lesnefsky AA, Lin F, Chen $Y$, Zaroff TA, Veloso AB, Xie B, McConnell CA, Ward RJ, Schwartz DR, et al: Evolution combined with genomic study elucidates genetic bases of isobutanol tolerance in Escherichia coli. Microb Cell Fact 2011, 10:18.

17. van Maris AJ, Winkler AA, Kuyper M, de Laat WT, van Dijken JP, Pronk JT: Development of efficient xylose fermentation in Saccharomyces cerevisiae: xylose isomerase as a key component. Adv Biochem Eng Biotechnol 2007, 108:179-204.

18. Guimaraes PM, Francois J, Parrou JL, Teixeira JA, Domingues L: Adaptive evolution of a lactose-consuming Saccharomyces cerevisiae recombinant. Appl Environ Microbiol 2008, 74:1748-1756.

19. Labbe S, Thiele DJ: Pipes and wiring: the regulation of copper uptake and distribution in yeast. Trends Microbiol 1999, 7:500-505.

20. Jamienson DJ: Oxidative stress response in the yeast Saccharomyces cerevisiae. Yeast 1998, 14:1511-1527.

21. Sarais I, Manzano M, De Bertoldi M, Romandini P, Beltramini M, Salvato B, Rocco GP: Adaptation of a Saccharomyces cerevisiae strain to high copper concentrations. Biometals 1994, 7:221-226.

22. Mrvcic J, Stanzer D, Stehlik-Tomas V, Skevin D, Grba S: Optimization of bioprocess for production of copper-enriched biomass of industrially important microorganism Saccharomyces cerevisiae. J Biosci Bioeng 2007, 103:331-337

23. Hewitt CJ, Nebe-Von-Caron G: The application of multi-parameter flow cytometry to monitor individual microbial cell physiological state. Adv Biochem Eng Biotechnol 2004, 89:197-223.

24. Deere D, Shen J, Vesey G, Bell P, Bissinger P, Veal D: Flow cytometry and cell sorting for yeast viability assessment and cell selection. Yeast 1998 14:147-160.

25. Sen M, Yilmaz U, Baysal A, Akman S, Cakar ZP: In vivo evolutionary engineering of a boron-resistant bacterium: Bacillus boroniphilus. Antonie Van Leeuwenhoek 2011, 99:825-835.

26. White C, Gadd GM: Uptake and cellular distribution of copper, cobalt and cadmium in strains of Saccharomyces cerevisiae cultured on elevated concentrations of these metals. FEMS Microbiol Ecol 1989, 38:277-283.

27. Joho M, Fujioka Y, Murayama T: Further studies on the subcellular distribution of $\mathrm{Cd} 2+$ in $\mathrm{Cd}$-sensitive and $\mathrm{Cd}$-resistant strains of Saccharomyces cerevisiae. J Gen Microbiol 1985, 131:3185-3191.

28. Avery SV, Howlett NG, Radice S: Copper toxicity towards Saccharomyces cerevisiae: dependence on plasma membrane fatty acid composition Appl Environ Microbiol 1996, 62:3960-3966.

29. Fernandes AR, Sa-Correia I: The activity of plasma membrane $\mathrm{H}(+)$-ATPase is strongly stimulated during Saccharomyces cerevisiae adaptation to growth under high copper stress, accompanying intracellular acidification. Yeast 2001, 18:511-521.

30. Vagabov VM, Ivanov AY, Kulakovskaya TV, Kulakovskaya EV, Petrov W, Kulaev IS: Efflux of potassium ions from cells and spheroplasts of Saccharomyces cerevisiae yeast treated with silver and copper ions. Biochemistry (Mosc) 2008, 73:1224-1227.

31. Abbott DA, Knijnenburg TA, de Poorter LM, Reinders MJ, Pronk JT, van Maris AJ: Generic and specific transcriptional responses to different weak organic acids in anaerobic chemostat cultures of Saccharomyces cerevisiae. FEMS Yeast Res 2007, 7:819-833.

32. Perrone GG, Tan SX, Dawes IW: Reactive oxygen species and yeast apoptosis. Biochim Biophys Acta 2008, 1783:1354-1368.

33. Fogel S, Welch JW: Tandem gene amplification mediates copper resistance in yeast. Proc Natl Acad Sci USA 1982, 79:5342-5346. 
34. Thomas JA, Poland B, Honzatko R: Protein sulfhydryls and their role in the antioxidant function of protein S-thiolation. Arch Biochem Biophys 1995, 319:1-9.

35. Grant CM, Quinn KA, Dawes IW: Differential protein S-thiolation of glyceraldehyde-3-phosphate dehydrogenase isoenzymes influences sensitivity to oxidative stress. Mol Cell Biol 1999, 19:2650-2656.

36. Duan X, Kelsen SG, Merali S: Proteomic analysis of oxidative stressresponsive proteins in human pneumocytes: insight into the regulation of DJ-1 expression. J Proteome Res 2008, 7:4955-4961.

37. Contreras L, Moenne A, Gaillard F, Potin P, Correa JA: Proteomic analysis and identification of copper stress-regulated proteins in the marine alga Scytosiphon gracilis (Phaeophyceae). Aquat Toxicol 96:85-89.

38. Morigasaki S, Shimada K, Ikner A, Yanagida M, Shiozaki K: Glycolytic enzyme GAPDH promotes peroxide stress signaling through multistep phosphorelay to a MAPK cascade. Mol Cell 2008, 30:108-113.

39. Krynetski EY, Krynetskaia NF, Gallo AE, Murti KG, Evans WE: A novel protein complex distinct from mismatch repair binds thioguanylated DNA. Mol Pharmacol 2001, 59:367-374.

40. Ishitani R, Sunaga K, Hirano A, Saunders P, Katsube N, Chuang DM: Evidence that glyceraldehyde-3-phosphate dehydrogenase is involved in age-induced apoptosis in mature cerebellar neurons in culture. $J$ Neurochem 1996, 66:928-935.

41. Hara MR, Agrawal N, Kim SF, Cascio MB, Fujimuro M, Ozeki Y, Takahashi M, Cheah JH, Tankou SK, Hester LD: S-nitrosylated GAPDH initiates apoptotic cell death by nuclear translocation following Siah1 binding. Nat Cell Biol 2005, 7:665-674.

42. Park SG, Cha MK, Jeong W, Kim IH: Distinct physiological functions of thiol peroxidase isoenzymes in Saccharomyces cerevisiae. J Biol Chem 2000, 275:5723-5732.

43. Gomez-Pastor R, Perez-Torrado R, Cabiscol E, Ros J, Matallana E: Reduction of oxidative cellular damage by overexpression of the thioredoxin TRX2 gene improves yield and quality of wine yeast dry active biomass. Microb Cell Fact 9:9.

44. Garrido EO, Grant CM: Role of thioredoxins in the response of Saccharomyces cerevisiae to oxidative stress induced by hydroperoxides. Mol Microbiol 2002, 43:993-1003.

45. Trotter EW, Rand JD, Vickerstaff J, Grant CM: The yeast Tsa1 peroxiredoxin is a ribosome-associated antioxidant. Biochem J 2008, 412:73-80.

46. Clemens MJ: Initiation factor elF2 alpha phosphorylation in stress responses and apoptosis. Prog Mol Subcell Biol 2001, 27:57-89.

47. Brenner AJ, Harris ED: A quantitative test for copper using bicinchoninic acid. Anal Biochem 1995, 226:80-84.

48. Bradford MM: A rapid and sensitive method for the quantitation of microgram quantities of protein utilizing the principle of protein-dye binding. Anal Biochem 1976, 72:248-254

49. Bergmeyer HU: Methods of enzymatic analysis. Verlag Chemie, Weinheim; 319833.

50. Mc Cord JM, Fridovich I: Superoxide dismutase: an enzymatic function for erythrocuprein chemocuprein. J Biol Chem 1969, 244:6049-6050.

51. Chance B, Maehly AC: Assay of catalase and peroxidase. Met Enzymol 1955, 2:773-775

52. Wendel A: Glutathione peroxidase. Enzym Bas Detox Jakoby W B (Ed) Acad Press NY 1980, 1:333.

53. Wang SH, Shih YH, Lin LY: Yeast consensus initiator sequence markedly enhances the synthesis of metallothionein III in Saccharomyces cerevisiae. Biotech Lett 1998, 20:9-13.

54. Laemmli UK: Cleavage of structural proteins during the assembly of the head of bacteriophage T4. Nature 1970, 5259:680-685.

doi:10.1186/1475-2859-11-1

Cite this article as: Adamo et al:: Laboratory evolution of copper

tolerant yeast strains. Microbial Cell Factories 2012 11:1.

\section{Submit your next manuscript to BioMed Central and take full advantage of:}

- Convenient online submission

- Thorough peer review

- No space constraints or color figure charges

- Immediate publication on acceptance

- Inclusion in PubMed, CAS, Scopus and Google Scholar

- Research which is freely available for redistribution

Submit your manuscript at www.biomedcentral.com/submit
Biomed Central 